\title{
Identifikasi Bidang Gelincir Tanah Longsor Menggunakan Metode Geolistrik Konfigurasi Schlumberger di Perumahan Ayudia Semarang
}

\author{
Sumarli*1 \& Rambu Ririnsia Harra Hau $^{2}$ \\ ${ }^{1}$ Program Studi Pendidikan Fisika, STKIP Singkawang \\ ${ }^{2}$ Program Studi Pendidikan Fisika, Universitas Nusa Nipa \\ *Email: sumarliphysics@gmail.com
}

Received: 30 November 2021; Accepted: 13 Desember 2021； Published: 20 Desember 2021 DOI: http://dx.doi.org/10.29303/jpft.v7i2.3168

\begin{abstract}
This study aims to identify the potential for landslides in the Ayudia housing location, Semarang. The data obtained in this study were apparent resistivity data using the geoelectric resistivity method of the Schlumberger configuration. Measurements were carried out on two tracks, namely the first track with a stretch length of $150 \mathrm{~m}$ and electrode spacing of $10 \mathrm{~m}$ and the second track with a stretch length of $75 \mathrm{~m}$ and electrode spacing of $5 \mathrm{~m}$. Res2dinv software was used to display the resistivity value on each track so that a color image is seen that describes the change in resistivity in each rock layer. The results of the study indicated the identification of the location of the slip plane on the first track with a layer that is suspected to be the slip plane, namely limestone with resistivity values (307939) $\mathbf{\Omega} \mathrm{m}$ and is at a depth of (19,9-26.9) $\mathrm{m}$. This layer had a higher resistivity contrast than the top layer of the slip plane in the form of sandstone which can store water content. Thus, it could be concluded that the first track identified the potential for landslides to occur.
\end{abstract}

Keywords: Slip Plane; Geoelectrical Resistivity; Schlumberger

\section{PENDAHULUAN}

Bencana geologi merupakan bencana yang terjadi akibat proses geologi secara alamiah yang siklus kejadiannya dimulai dari skala beberapa tahun hingga jutaan tahun. Klasifikasi bencana geologi meliputi gempa bumi, gelombang tsunami, letusan gunung api, gerakan massa tanah dan batuan atau longsor serta banjir (Purnama, Darmawan, \& Wibowo, 2016). Bencana geologi seperti gempa bumi, gelombang tsunami, letusan gunung api merupakan bencana murni yang disebabkan oleh proses geologi sehingga tidak dapat dicegah sedangkan bencana geologi berupa gerakan massa tanah dan batuan atau longsor serta banjir sering terjadi akibat kondisi geologinya yang rawan dan juga dipicu oleh aktivitas manusia (Heradian \& Arman, 2015).

Longsor merupakan salah satu bencana alam yang sering terjadi di Indonesia yang mengakibatkan kerugian materiil yang cukup besar serta menelan korban jiwa (Wakhidah,
Khumaedi, \& Dwijananti, 2014). Longsor lebih sering ditemukan pada lapangan yang tidak horizontal serta dipengaruhi komponen gravitasi. Gaya garivitasi dan rembesan merupakan penyebab utama ketidakstabilan yang terjadi pada lereng. Bencana tanah longsor sering dikaitkan dengan datangnya musim penghujan (Darsono, Nuslaksito, \& Legowo, 2012). Salah satu penyebab bencana tanah longsor yang sangat berpengaruh adalah bidang gelincir atau bidang geser (Sugito, Irayani, \& Jati, 2010). Bidang gelincir merupakan bidang yang bersifat menahan air (permeabilitas rendah), bersifat padat yang memungkinkan tanah pelapukan bergerak di atasnya (Dona, Akman, \& Sudiar, 2015). Bidang gelincir di daerah longsor ditandai dengan adanya dua lapisan tanah/batuan yang nilai tahanan jenisnya sangat kontras (Wahyono et al., 2011; VSI, 2016). Bidang gelincir biasanya terdiri dari lapisan yang keras dengan lapisan yang lunak dimana lapisan yang keras (kedap 
air) akan menjadi licin jika terjadi hujan dan lapisan lunak akan bergerak melalui lapisan kedap yang berperan sebagai material longsor (Retnaningtiyas, Sutrisni, \& Indriawan, 2015). Material longsor dicirikan dengan nilai-nilai resistivitas rendah dan bidang longsor ditandai dengan material yang memiliki resistivitas tinggi (Perrone, Sabatino, \& Vicenzo, 2012).

Penelitian ini bertujuan untuk mengidentifikasi bidang gelincir yang diduga sebagai penyebab terjadinya tanah longsor di perumahan Ayudia Sekaran Kota Semarang Jawa Tengah dengan menggunakan metode geolistrik resistivitas konfigurasi Schlumberger. Metode geolistrik tidak merusak lingkungan, relatif murah dan mampu mendeteksi sampai kedalaman tertentu (Virman, Lasmono, \& Massinai, 2013).

\section{METODE PENELITIAN}

Tahapan kegiatan penelitian meliputi survei pendahuluan, pengambilan data geolistrik, pengolahan data dan interpretasi. Survei pendahuluan dimaksudkan untuk pengurusan ijin penelitian, melakukan survei lokasi penelitian, kemudian menentukan tempat lokasi dan lintasan yang sesuai untuk melakukan penelitian. Terdapat dua lintasan yang diteliti dengan panjang lintasan pertama 150 meter dan lintasan kedua 75 meter. Lebar spasi jarak elektroda 10 meter untuk lintasan pertama dan 5 meter untuk lintasan kedua. Metode akuisisi data geolistrik resistivitas yaitu resistivity sounding. Resistivity sounding dimaksudkan untuk memperkirakan variasi resistivitas batuan secara vertikal sebagai fungsi dari kedalaman (Sugito et al., 2010). Susunan elektroda metode resistivity sounding menggunakan konfigurasi Schlumberger.

Pengambilan data resistivitas yaitu penancapan elektroda arus dan potensial dengan menggunakan alat Resistivitymeter.
Tahapan pengolahan data dilakukan dengan menghitung nilai apparent resistivity $\left(\rho_{\mathrm{a}}\right)$ dengan memasukkan nilai $\Delta V$ (beda potensial), $I$ (kuat arus listrik), $a$ (jarak antara dua elektroda) dan $K$ (faktor geometri) ke dalam program Microsoft Excel. Selanjutnya interpretasi dan pemodelan perlapisan batuan menggunakan software Res2Dinv dengan menghasilkan kontur struktur lapisan batuan.

Data yang diperoleh kemudian diinterpretasikan nilai resistivitas lapisanlapisan batuan bawah permukaan berdasarkan nilai resistivitas materialmaterial bumi seperti ditampilkan pada Tabel 1. Data hasil interpretasi ini kemudian disesuaikan lagi dengan peta geologi kota Semarang yang menggambarkan topografi kota Semarang terutama pada lokasi penelitian.

Tabel 1. Nilai Resistivitas Material-Material

\begin{tabular}{lc}
\multicolumn{2}{c}{ Bumi (Telford et al., 1990$)$} \\
\hline Bahan & Resistivitas \\
& $(\Omega \mathrm{m})$ \\
\hline Air (udara) & $\sim$ \\
Limestones (batu gamping) & $50-10^{7}$ \\
Alluvium & $10-800$ \\
Sandstone (batu pasir) & $1-1.10^{3}$ \\
Clay (Lempung) & $1-1.10^{2}$ \\
Konglomerat & $2.10^{3}-10^{4}$ \\
Pasir Lempungan & $20-2.10^{3}$ \\
(Consolidated shales) & $0,5-300$ \\
Ground water (air tanah) & \\
\hline
\end{tabular}

\section{HASIL DAN PEMBAHASAN}

Berikut ini disajikan hasil dan pembahasan berdasarkan penelitian yang telah dilakukan.

\section{Hasil}

Pengukuran geolistrik resistivitas pada lintasan pertama dilakukan pada lintasan sepanjang $150 \mathrm{~m}$ dengan arah lintasan selatan-utara dimana bagian selatan lebih rendah daripada bagian utara. Titik $0 \mathrm{~m}$ berada pada ketinggian $160 \mathrm{~m}$ dpl dan titik $150 \mathrm{~m}$ berada pada ketinggian $169 \mathrm{~m}$ dpl. Hasil pengolahan data topografi melalui software Res2Dinv dengan iterasi 3 dan 
error $102,1 \%$, diperoleh kontur 2D nilai resistivitas bervariasi antara $1,15 \Omega \mathrm{m}$ sampai dengan $939 \Omega$ m seperti ditunjukkan Gambar 1.

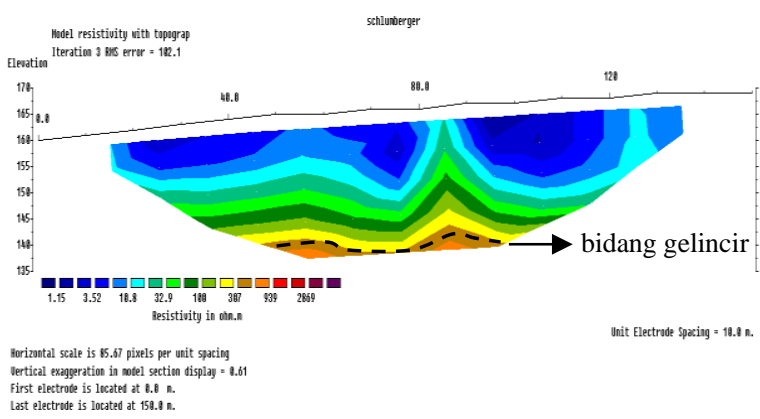

Gambar 1. Citra 2D nilai resistivitas bawah permukaan pada lintasan pertama dengan topografi

Berdasarkan Gambar 1, dapat diinterpretasikan lapisan-lapisan batuan bawah permukaan antara lain lapisan pertama memiliki nilai resistivitas $(1,15$ $10,8) \Omega m$ dengan warna biru tua sampai biru muda dan berada pada kedalaman $(2,50$ 13,5) m. Lapisan ini disesuaikan dengan Tabel 1 dan diperkirakan sebagai batu lempung. Lapisan kedua memiliki nilai resistivitas (21,85-32,9) $\Omega \mathrm{m}$ dengan warna biru kehijauan sampai hijau muda dan berada pada kedalaman (13,5-19,9) m diperkirakan sebagai pasir lempungan. Lapisan ketiga memiliki nilai resistivitas $(66,45-203,5) \Omega m$ dengan warna hijau tua sampai hijau kekuningan dan berada pada kedalaman (19,9-26,9) m diperkirakan sebagai batu pasir. Lapisan keempat memiliki nilai resistivitas (307-939) $\Omega \mathrm{m}$ dengan warna cokelat sampai jingga dan berada pada kedalaman (19,9-26,9) m diperkirakan sebagai batu gamping. Lapisan batu gamping ini diduga sebagai bidang gelincir pada lintasan pertama.

Pengukuran geolistrik resistivitas pada lintasan kedua dilakukan pada lintasan sepanjang $75 \mathrm{~m}$ dengan arah lintasan barattimur dimana bagian barat lebih rendah daripada bagian timur. Titik $0 \mathrm{~m}$ berada pada ketinggian $134 \mathrm{~m}$ dpl dan titik $75 \mathrm{~m}$ berada pada ketinggian $162 \mathrm{~m}$ dpl. Hasil pengolahan data topografi melalui software Res2Dinv dengan iterasi 3 dan error 78,7\%, diperoleh kontur 2D nilai resistivitas bervariasi antara $0,327 \Omega$ m sampai dengan $449 \Omega \mathrm{m}$ seperti ditunjukkan Gambar 2.

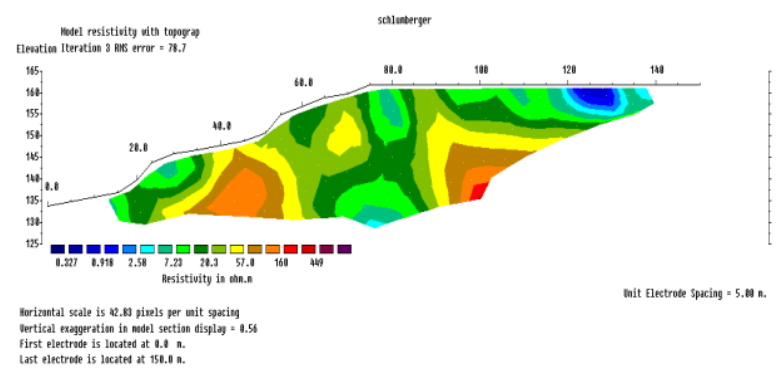

Gambar 2. Citra 2D nilai resistivitas bawah permukaan pada lintasan kedua dengan topografi

Berdasarkan Gambar 2, dapat diinterpretasikan lapisan-lapisan batuan bawah permukaan diantaranya lapisan pertama memiliki nilai resistivitas $(0,327$ $1,75) \Omega$ m dengan warna biru tua dan berada pada kedalaman (1,25-6,76) m diperkirakan sebagai daerah resapan air. Lapisan kedua memiliki nilai resistivitas $(2,58-13,77) \Omega \mathrm{m}$ dengan warna biru muda sampai hijau muda dan berada pada kedalaman $(1,25-13,4) \mathrm{m}$ dan (21,5-31,3) m diperkirakan sebagai batu lempung. Lapisan ketiga memiliki nilai resistivitas $(20,3-57,0) \Omega m$ dengan warna hijau kekuningan sampai kuning dan berada pada kedalaman $(1,25-31,3) \mathrm{m}$ diperkirakan sebagai pasir lempungan. Lapisan keempat memiliki nilai resistivitas (108,5-160) $\Omega \mathrm{m}$ dengan warna cokelat sampai jingga dan berada pada kedalaman (1,25-31,3) $\mathrm{m}$ diperkirakan sebagai batu pasir. Lapisan kelima memiliki nilai resistivitas (304,5449) $\Omega$ m dengan warna merah sampai ungu dan berada pada kedalaman $(26,2-31,3) \mathrm{m}$ diperkirakan sebagai batu gamping. Susunan lapisan-lapisan batuan bawah permukaan pada lintasan kedua terlihat acak dan tidak 
beraturan serta terdapat banyak patahanpatahan sehingga tidak dapat diperkirakan dugaan keberadaan bidang gelincir pada lintasan ini.

\section{Pembahasan}

Berdasarkan peta geologi kota Semarang terutama pada lokasi penelitian di daerah Banaran diperkirakan bahwa struktur lapisan batuan pada lokasi penelitian termasuk pada lapisan satuan breksi vulkanik formasi kaligetas yang menimpa lapisan satuan batu lempung formasi kerek. Satuan breksi vulkanik formasi kaligetas terdiri dari breksi vulkanik, aliran lava, tuf, batu pasir tufan dan batu lempung yang memiliki ketebalan berkisar antara (50-200) m. Sementara satuan batu lempung formasi kerek terdiri dari perselingan batu lempung, napal, batu pasir tufan, konglomerat, breksi vulkanik dan batu gamping yang memiliki ketebalan total lebih dari $400 \mathrm{~m}$ (Thanden, 1996).

Bidang gelincir diperoleh kontras resistivitas antar dua batuan yang saling berdekatan. Bila resistivitas diatasnya jauh lebih rendah, maka sangat memungkinkan terjadi longsoran. Lapisan yang memiliki banyak kandungan air akan memiliki resistivitas lebih rendah daripada lapisan yang memiliki sedikit kandungan air. Lapisan batu gamping ini diduga sebagai bidang gelincir pada lintasan pertama seperti ditunjukkan pada Gambar 1 dengan tanda garis putus-putus. Lapisan batu gamping memiliki nilai resistivitas yang jauh lebih besar dibandingkan dengan ketiga lapisan lainnya. Hal ini menunjukkan lapisan tersebut merupakan lapisan yang lebih kedap air dibandingkan dengan ketiga lapisan di atasnya (Herlin \& Budiman, 2012; Sy \& Budiman, 2013; Wakhidah et al., 2014).

Lapisan-lapisan bagian atas bidang gelincir yang terdeteksi diduga sebagai lapisan batuan lapuk yaitu lapisan batu lempung (clay), pasir lempungan (consolidated shales), dan batu pasir (sandstone) yang dapat menyimpan kandungan air. Jika curah hujan tinggi kemungkinan air akan terakumulasi pada lapisan-lapisan tersebut sehingga berakibat terjadinya longsor karena adanya pergerakan tanah pada lapisan-lapisan tersebut. Gerakan tanah atau gelinciran berupa translasi karena pola bidang gelincir berbentuk rata atau menggelombang landai (Herlin \& Budiman, 2012; Sy \& Budiman, 2013; Wakhidah et al., 2014).

\section{PENUTUP}

Berdasarkan hasil penelitian dapat disimpulkan bahwa lapisan batuan di lokasi penelitian dari permukaan atas ke bawah berupa tanah, batu lempung, pasir lempungan, batu pasir dan batu gamping. Dugaan keberadaan bidang gelincir terdapat pada lintasan pertama yang berupa lapisan batu gamping dengan nilai resistivitas (307939) $\Omega \mathrm{m}$ dan berada pada kedalaman $(19,9$ 26,9) m. Hal ini mengindikasikan bahwa pada lintasan pertama berpotensi terjadinya tanah longsor.

\section{REFERENSI}

Darsono, Nuslaksito, B., \& Legowo, B. (2012). Identifikasi Bidang Gelincir Pemicu Bencana Tanah Longsor Dengan Metode Resistivitas 2 Dimensi di Desa Pablengan Kecamatan Matesih Kabupaten Karanganyar. Indonesian Journal of Applied Physics, 2(1), 57-66.

Dona, I. R., Akman, \& Sudiar, N. Y. (2015). Identifikasi Bidang Gelincir Menggunakan Metode Geolistrik Tahanan Jenis Konfigurasi Schlumberger di Bukit Lantiak Kecamatan Padang Selatan. Jurnal Pillar of Physics, 5.

Heradian, E. A. \& Arman, Y. (2015). Pendugaan Bidang Gelincir Tanah 
Longsor di Desa Aruk Kecamatan Sajingan Kabupaten Sambas Dengan Menggunakan Metode Tahanan Jenis. Jurnal Prisma Fisika, 3(2), 5661.

Herlin, H. S. \& Budiman, A. (2012). Penentuan Bidang Gelincir Gerakan Tanah dengan Aplikasi Geolistrik Metode Tahanan Jenis Dua Dimensi Konfigurasi Wenner-Schlumberger (Studi Kasus Di Sekitar Gedung Fakultas Kedokteran Universitas Andalas Limau Manis, Padang). Jurnal Fisika Unand, 1(1), 19-24.

Perrone, A., Sabatino, P., \& Vicenzo, L. (2012). Electrical Resistivity Tomographies for Landslide Monitoring: a Review. Berichte Geol B-A.93, ISSN 1017-8880.

Purnama, A. Y., Darmawan, D., \& Wibowo, N. B. (2016). Interpretasi Bawah Permukaan Zona Kerentanan Longsor di Desa Gerbosari Kecamatan Samigaluh Kabupaten Kulonprogo Menggunakan Metode Geolistrik Konfigurasi DipoleDipole. Jurnal Pendidikan Matematika dan Sains UNY.

Retnaningtiyas, D., Sutrisni, \& Indriawan, B. (2015). Identifikasi Bidang Gelincir di Sekitar Songgoriti Kota Batu Sebagai Langkah Awal Mitigasi Bencana Tanah Longsor. Jurnal Fisika UM.

Sugito, Irayani, Z., \& Jati, I. P. (2010). Investigasi Bidang Gelincir Tanah Longsor Menggunakan Metode Geolistrik Tahanan Jenis di Desa Kebarongan Kecamatan Kemranjen Kabupaten Banyumas. Jurnal Berkala Fisika, 13(2), 49-54.

Sy, M. I. \& Budiman, A. (2013). Investigasi Bidang Gelincir Pada Lereng Menggunakan Metode Geolistrik Tahanan Jenis Dua Dimensi (Studi Kasus: Kelurahan Lumbung Bukit Kecamatan Pauh Padang). Jurnal Fisika Unand, 2(2), 88-93.

Telford, W. M., Geldard, L. P., Sheriff, R. E.
\& Keys, A. (1990). Applied Geophysics Second Edition. USA: Cambridge University Press.

Thanden, R. E., Sumadirdja, H., Richards, P. W., Sutisna, K., \& Amin, T. C. (1996). Peta Geologi Lembar Magelang dan Semarang, Jawa. Edisi kedua. Pusat Penelitian dan Pengembangan Geologi.

Virman, Lasmono, P. G., \& Massinai, M. A. (2013). Identifikasi Bidang Gelincir Daerah Kepulauan Serui Menggunakan Metode Geolistrik Tahanan Jenis. Seminar Nasional Fisika Unhas Makassar.

VSI (Vulcanology Survey of Indonesia). (2016). Pengenalan Gerakan Tanah Departemen Energi dan Sumber Daya Mineral. Diperoleh dari http://ESDM.ac.id/pengenalan_gera kan_tanah/VSI (diunduh pada 8 Desember 2016).

Wahyono, S. C., Hidayat, T. A., Pariadi, Novianti, R. F., Dewi, R. K., \& Minarto, O. (2011). Aplikasi Metode Tahanan Jenis 2D Untuk Mengidentifikasi Potensi Daerah Rawan Longsor di Gunung Kupang Banjarbaru. Jurnal Ilmiah Fisika FLUX, 8(2), 95-103.

Wakhidah, N., Khumaedi, \& Dwijananti, P. (2014). Identifikasi Pergerakan Tanah Dengan Aplikasi Metode Geolistrik Konfigurasi WennerSchlumberger di Deliksari Gunungpati Semarang. Unnes Physics Journal, 3(1), 1-6. 